\title{
Rethinking Sustainability: A Bibliometric and Visualisation of E-Waste Management in Africa
}

\author{
Vusumuzi Maphosa \\ Lupane State University
}

In bridging the digital divide and enhancing participation in the knowledge economy, most developing countries permit the importation of second-hand electronic equipment. The Global North exports over $80 \%$ of e-waste into the Global South; this is perceived as the neo-colonisation and decarbonisation divide. Rising e-waste in developing countries is an environmental and epidemiological crisis due to limited recycling infrastructure and environmental policies. This study performed a bibliometric analysis and visualisation of e-waste management in Africa. The initial Web of Science database search yielded 519,441 articles and refined them to 29 relevant articles. Results show the geographic distribution of articles, citation trends, H-index and keyword analysis. South Africa leads on publications, followed by Ghana, and new themes emerge. E-waste management research is rising, with over $60 \%$ of the articles published in the last five years. The publications have an $\mathrm{H}$-index of 14 , and the keyword analysis identified three distinct clusters. The study contributes to literature and challenges policymakers to craft policies that support the sustainable management of e-waste.

Keywords: electronic-waste, policy, recycling, e-waste management, conventions and treaties, Web of Science, VOS viewer, H-index

\section{INTRODUCTION AND BACKGROUND}

The last few decades have witnessed significant urbanisation of the African continent, offering prospects to improve living standards, nevertheless with some associated challenges. Over six billion people will live in urban centres by 2050, and Africa is leading the urban growth rate (UN-DESA, 2014). Solid waste in towns and cities has rapidly increased, posing environmental and health challenges due to urbanisation and socio-economic development. The world has witnessed a proliferation and adoption of electrical and electronic equipment (EEE) through urbanisation such as mobile phones, computers, refrigerators, musical devices, and many others. Businesses use EEE to drive production and automation, while consumers use technology for entertainment and accessing services. Consumers quickly replace EEE when it is no longer useful or after a new model is released. Garlapati (2016) notes that technological breakthroughs have allowed for rapid development of cheaper EEE, coupled with changing consumer demands increasing the rate of obsoleteness. The electronics industry has shaped socio-economic development and influenced daily living (Zeng \& Li, 2016). EEE has undeniably improved the standard of life, but it severely affects human health and the environment once discarded. Most e-waste management challenges are related to sustainability, environmental degradation and human health (Akon-Yamga, Daniels, Quaye, Ting, \& Asante, 2021). 
The rise of the knowledge economy, the innate desire for constant communication, and improvements in technological gadgets' design and development have resulted in EEE being frequently outdated and discarded. Many people in developing countries find it challenging to acquire new EEE to participate in the knowledge economy and often opt for used EEE. Sovacool (2019) reported the prevalence of low-quality devices and increased the importation of used EEE with reduced lifespans across Africa. Electronic waste (e-waste) refers to EEE that is discarded as it is no longer useful to the users; and includes computers, laptops, mobile phones, television sets, fridges, and others (Wang, Tian, Zhu, \& Zhong, 2017; OtengAbabioa \& Amankwaa, 2014). Over 1000 different substances are used during the manufacture of EEE, some being toxic elements, while others are precious metals (Widmer, Oswald-Krapf, Sinha-Khetriwal, Schnellmann, \& Boni, 2005). The high volume of e-waste generated has raised ecological concerns as it contains hazardous chemicals such as lead, chromium, mercury, and many more.

E-waste flow is one-way from developed to emerging countries. Sovacool (2019) described it as a neocolonial and decarbonisation divide. Garlapati (2016) observed that developed countries shipped e-waste for processing in emerging countries that lack policies and infrastructure, resulting in the burning of e-waste and disposal in landfills. Ikhlayel (2018) noted the accumulation of e-waste in developing countries due to inefficient collection systems, inadequate recycling infrastructure, and lack of policies. Informal recycling is the most dominant e-waste management strategy used in emerging economies. According to Garlapati (2016), developing countries have no appropriate processes to effectively manage e-waste due to the inability to separate, collect, store, transport, and dispose of e-waste.

The demand for used EEE in Africa continues to rise due to low-income levels and poor economic activities; however, non-functional and unusable EEE is often shipped to Africa. The Greenpeace report highlighted that up to $75 \%$ of second-hand EEE imported into Africa was unusable and unrepairable (Marriott, 2011). Despite many policies, conventions and treaties, the transboundary restriction of the ewaste movement has failed. One major challenge in managing e-waste in emerging economies is the lack of resources and capacity to implement policies and legislation (Karin, 2012). Political will is lacking in implementing sustainable e-waste management, and this has been witnessed by the low ratification of treaties and conventions aimed at managing e-waste. For example, only 30 countries are signatories to the Bamako Declaration 20 years after its adoption (Mutsau, Billiat, \& Musingafi, 2015). One of the top exporters of e-waste, the USA, has not ratified the Basel convention (Lepawsky, Akese, Billah, Conolly, \& Mcnabb, 2015). Most of the conventions and treaties' shortcomings are lack of enforcement, accountability, and monitoring, especially in emerging economies with weak environmental policies and systems prone to corruption.

Ogunlade (2010) noted that hazardous waste often travels through a path of least resistance, typically from the West to the South. Industry experts contend that all e-waste exports into developing countries should be prohibited as importing countries cannot recycle or appropriately discard e-waste due to inadequate infrastructure (Schmidt, 2006). To contain and restrict the neo-colonial and decarbonisation divide (Sovacool, 2019), the Basel Action Network (BAN) prohibits the movement of hazardous waste between countries. The BAN calls for a consent between the exporting and importing countries, but these are usually breached due to corruption, illegal activities and the inability to classify used EEE (Olowu, 2012). One major weakness of the treaty is that it is silent on the violators' liability, and therefore, e-waste continues to flow disguised as working EEE.

In 1998, African countries realised some shortcomings of the Basel Convention and established the Bamako Convention, which banned the importation of hazardous waste into Africa (UNEP, n.d.). The convention allows the transboundary movement of hazardous wastes generated within Africa under certain stringent conditions. This means that more-developed countries in Africa can ship e-waste to less-developed ones, and this is highlighted as a significant limitation of the Basel Convention. The 2006 Nairobi ministerial declaration on e-waste affirmed support of the Basel Convention and pledged to promote the green design of EEE and the phasing out of hazardous substances and prevent the export of end-of-life EEE and introduce the extended producer responsibilities (Schluep, 2010). The Durban Declaration aims to increase governance and public awareness of e-waste, encourage countries to create institutional policies, and develop collection and recycling infrastructure (Schluep, 2010; Marriott, 2011). The Durban 
declaration implores African countries to review existing waste management policies, including e-waste regulation and management.

E-waste is growing at about $5 \%$ per annum more than any other solid waste stream, and the annual global generation is estimated to be about 50 million tons, of which 50 to $80 \%$ is exported to developing countries (Perkins, Drisse, Nxele, \& Sly, 2014). Hossain and Rahman (2020) reported that global e-waste production was 53.6 million tons in 2019 and would increase to 74.7 million tons by 2030. In 2014 e-waste generated within Africa was estimated to be 1.9 million tons, with Egypt accounting for 0.37 million tons, South Africa had 0.35 million tons and Nigeria with 0.22 million tons (The Global E-waste Monitor, 2014). In addition to the 1.9 million tons of domestic e-waste, Rajaram and Pekeur (2014) reported that developed countries would export 50-80\% of e-waste into Africa and China. Africa carries the largest share of e-waste challenges, though it hosts few direct EEE manufacturers. By 2017, it generated 2.2 million tons, most of it being imported new and used EEE (Baldé, Forti, Gray, Kuehr, \& Stegmann, 2017). The Global North exported about $80 \%$ of its e-waste output illegally to developing countries (Yu, Akormedi, Asampong, Meyer, \& Fobil, 2017). Baldé et al. (2017) reported that locally generated e-waste in Africa was about 50\%, while the rest came through illegal transboundary imports from the West.

Lack of political will and inadequate policies have seen the continuous export of e-waste to emerging nations. Ogunlade (2010) reported that corrupt and weak political leadership in emerging economies is stifling efforts to control imports of e-waste through porous borders riddled with corruption. It costs US\$20 to recycle a computer in the USA, whereas through the use of informal systems, it costs US $\$ 4$ to recycle a computer in emerging economies (Nnorom \& Osibanjo, 2008). Karin (2012) predicted that South Africa and China would witness a $400 \%$ increase in e-waste generated from computers compared to 2007 levels.

Most developed countries have formulated and implemented policies, collection systems, allocated financial resources for formal recycling infrastructure, and created public awareness on the effects of ewaste on the environment and human health. The European Union's WEEE Directive has set collection and recycling targets of $85 \%$ of the domestically generated e-waste through stringent measures (European Commission, 2013). In developed countries, EEE producers and municipalities coordinate the collection and recycling of e-waste through formal channels guided by effective policies (Maphosa \& Maphosa, 2020). E-waste is collected separately from municipal solid waste and sorted according to recycling and disposal categories (Kazancoglu, Ozbiltekin, \& Ozen, 2021). Switzerland has funded and partnered with many developing countries such as South Africa, China and Columbia to establish environmentally friendly and resource-conserving practices to recover materials from e-waste (Rajaram \& Pekeur, 2014). Baldé et al. (2017) report that only 5\% of e-waste generated in Africa is recycled. In Ghana, about $40-60 \%$ of domestically generated e-waste is recycled, with the informal sector accounting for about $95 \%$ of the recycled waste (Oteng-Ababioa \& Amankwaa, 2014).

Millions of tons of e-waste are exported into Africa yearly in the pretext of bridging the digital divide. Most of the used EEE is obsolete and unrepairable and end up in landfills, polluting the environment through indiscriminate burning (Maphosa \& Maphosa, 2020; Umesi \& Onyia, 2008). Research shows that West Africa is a major trading route for e-waste, with Ghana and Nigeria being the major import ports (Maphosa \& Maphosa, 2020; Karin, 2012; Terada, 2012). Shorter product lifespans have significantly increased the obsoleteness of EEE as they quickly reach their end of useful life. Over the years, the computers' lifespan has reduced from 5-10 years to about 3-4 years, thereby fueling e-waste (Agamuthu, Kasapo, \& Nordin, 2015). Schmidt (2006) reported that over 500 shipping containers are offloaded every month in Lagos ports, with up to $75 \%$ of the contents unusable. The two main ports in Lagos receive about 70000 tons of e-waste imported from the UK, Belgium, Germany and the USA, with basic tests showing that at least $19 \%$ of the devices were not working (Odeyingbo, Nnorom, \& Deubzer, 2017).

The rise of the knowledge economy has witnessed increased EEE demand, and Africa has relied on imported used EEE. However, the lack of policies has increased the environmental and health challenges through indiscriminate burning to recover precious minerals (Maphosa \& Maphosa, 2020). Thus e-waste has become a global issue, and considerable research has been done on the effects of improper handling and disposal, which has disastrous consequences on the environment and human health (Rajaram \& Pekeur, 2014). E-waste management challenges are more pronounced in developing countries with inadequate 
environmental management systems, lack of policies and unavailability of recycling infrastructure (Miner, Rampedi, Ifegbesan, \& Machete, 2020). Most of the e-waste is collected and disposed of together with municipal waste, which is detrimental to human health and the environment. Forti et al. (2020) lamented that the intensity of informal activities in managing e-waste in developing countries was suitable for local economies but detrimental to the environment and human health.

Several studies have revealed adverse effects of improper e-waste management on human health and the environment (Maphosa \& Maphosa, 2020; Bakhiyia, Gravela, Ceballos, Flynnd, \& Zayeda, 2018; Karin, 2012). In Africa, less than $10 \%$ of e-waste is recycled due to the unavailability of take-back schemes, a highly informal economy and a lack of financing for collectors (Rajaram \& Pekeur, 2014). Crude recycling causes severe environmental degradation and negatively impacts human health. Karin (2012) reported that informal e-waste workers suffered high incidences of congenital disabilities, infant mortality, various cancers, kidney failure, brain damage and many respiratory diseases. In developing countries, management and recycling of e-waste are done through crude and rudimentary processes with insufficient safety regulations. Due to the lack of formal e-waste management options in emerging economies, the sector has become highly informal (Forti, Baldé, Kuehr, \& Bel, 2020). Informal workers use inefficient tools such as stones, chisels, and hammers to break down components, leading to musculoskeletal injuries (Adanu, Gbedemah, \& Attah, 2020). The recovery of precious minerals found in e-waste involves smashing and burning components in open spaces (Akon-Yamga, Daniels, Quaye, Ting, \& Asante, 2021).

Schmidt (2006) reports that informal recycling through backyard practices involves exploiting women and children who cook printed circuit boards and burn cables in open flames to extract precious metals. Those affected by informal e-waste processing include children and pregnant women who live near dumpsites and informal workers who use primitive methods to extract precious metals (Bakhiyia, Gravela, Ceballos, Flynnd, \& Zayeda, 2018). Children between 11 and 18 years are engaged in burning and dismantling used EEE at the Agbogbloshie e-waste site in Ghana (Karin, 2012). More awareness programmes are needed for informal e-waste workers and incentives to encourage environmentally friendly material recovery techniques. Failure to adopt environmentally friendly e-waste management methods is caused by lack of awareness, inadequate legislation, inadequate infrastructure and lack of knowledge on appropriate disposal (Maphosa \& Maphosa, 2020; Oteng-Ababioa \& Amankwaa, 2014; Herat \& Agamuthu, 2012).

Out of the 1000 substances found in e-waste, some are non-ferrous minerals such as copper, aluminium and rare minerals such as europium, terbium, dysprosium, platinum and gold, whose recycling potential is over 55 billion euros (Baldé, Forti, Gray, Kuehr, \& Stegmann, 2017). E-waste management and recycling is a lucrative business as Oteng-Ababioa, and Amankwaa (2014) reported that Ghana generated between US $\$ 105$ to US\$268 million from e-waste activities with over 200000 directly employed in the e-waste ecosystem. Every day, over 5000 scrap-metal dealers search for valuable materials such as copper and aluminium from the Agbogbloshie in Ghana (Forti, Baldé, Kuehr, \& Bel, 2020). Unfortunately, in many African countries such as Nigeria, Ghana and South Africa, acid is used to extract precious minerals such as platinum, gold, cadmium and palladium from PCBs (Ikhlayel, 2018).

Most of the African economy is informal, and the massive demand for precious minerals recovered from e-waste makes the informal e-waste sector a thriving business (Akon-Yamga, Daniels, Quaye, Ting, \& Asante, 2021). After informal recycling, the recovered gold and silver is turned into jewellery and exported to Singapore, India and Japan, with some sold domestically (Lepawsky, Akese, Billah, Conolly, $\&$ Mcnabb, 2015). South Africa has the best recycling facilities in Africa, supported by specific e-waste legislation where most e-waste is recycled (Rajaram \& Pekeur, 2014). Forti et al. (2020) noted that Morocco, South Africa, Namibia and Rwanda had set up facilities for e-waste recycling even though the informal sector still dominated the sector. In Ghana, copper, aluminium and steel recovered from e-waste recycling are sent to factories and foundries for melting and producing various products (Lepawsky, Akese, Billah, Conolly, \& Mcnabb, 2015). Some African governments are interested in adopting comprehensive e-waste management plans to integrate the informal sector into official management systems, establishing take-back schemes and EPR (Baldé, Forti, Gray, Kuehr, \& Stegmann, 2017).

The research questions for this study are: 
- What is the geographic distribution of e-waste research in Africa regarding where the authors are based?

- What are the publication and citation trends of research on e-waste in Africa?

- Which research topics are covered by the research articles on e-waste in Africa?

- What deductions can be made from the H-Index analysis and keyword analysis of publication on e-waste research in Africa?

This paper provides a bibliometric and visualisation of research trends on e-waste management in Africa over the past two decades. This study explores the geographic distribution of publications, publication and citation trends, research topics covered in the articles, the H-Index analysis and keyword analysis. It provides valuable literature for future research and policy guidelines. The past few decades have witnessed a rise in e-waste management research as global environmental issues have become prominent. There is a general lack of public awareness of e-waste in developing countries.

\section{METHODS}

The study used the Web of Science database, a comprehensive and widely used repository for bibliometric analysis, to collect data related to e-waste research in Africa. An iterative strategy was used to search for articles about e-waste in Africa. The research focused on articles related to different aspects of e-waste such as e-waste management, e-waste policy, e-waste disposal or e-waste recycling.

Firstly, searching focused on articles with titles relating to e-waste using the following string: TI=(( electrical waste OR electronic equipment waste OR electrical garbage OR e-waste OR end-of-lifeelectronic equipment OR e-waste management OR e-waste policy OR e-waste disposal OR e-waste recycling ), where TI represents titles in the Web of Science repository. Four Web of Science core collection indexes were searched - Science Citation Index Expanded, Social Science Citation Index, Humanities and Arts Citation Index and the Emerging Sources Citation Index. This search (search \# 1) gave 519441 articles. Secondly, the search narrowed to articles relating to Africa, using the following search string: TI=( Africa*) OR TS $=($ Africa* $)$ OR AB $=($ Africa* $)$ OR AK $=($ Africa* $)$, where TS represents a topic, $\mathrm{AB}-$ abstract and AK area. This search (search \# 2) yielded 1619 articles.

The Web of Science functionality combined searches using Boolean connectors such as AND or OR. Combining search \# 1 and search \# 2 through the AND operator yielded 47 articles in both search results. The 47 articles were exported to MS Excel for analysis. The 47 titles were analysed to ensure that they were related to e-waste and Africa. Articles that did not relate to e-waste and Africa were excluded, leaving 29 articles in the review.

Table 1 shows the document types of the articles included in this study. The majority of the documents retrieved are research articles (78.3\%), reviews (17.2\%) and editorial material (3.5\%). Notably, none of the pieces was conference proceeding papers, book chapters, books, news items or retracted articles.

\section{TABLE 1}

\section{DOCUMENT TYPES OF ARTICLES RETRIEVED}

\begin{tabular}{|l|l|l|}
\hline Document Type & Count & Percentage \\
\hline Article & 23 & 79.3 \\
\hline Reviews & 5 & 17.2 \\
\hline Editorial material & 1 & 3.5 \\
\hline Total & 29 & 100 \\
\hline
\end{tabular}




\section{RESULTS}

\section{Geographic Distribution of Publications}

The articles' distribution was analysed based on the author's affiliation and country of origin across the African continent. The analysis shows that 20 countries contributed to e-waste research in Africa. Figure 1 gives the geographical map showing publications. A map was created using Displayr (https://www.displayr.com/), an online tool that plots the publication stats per country on the map. The map contains an index that shows the publication scale. On the map, all countries in white have not published any research on e-waste in Africa.

\section{FIGURE 1 \\ THE GEOGRAPHICAL LOCATION OF STUDIES}

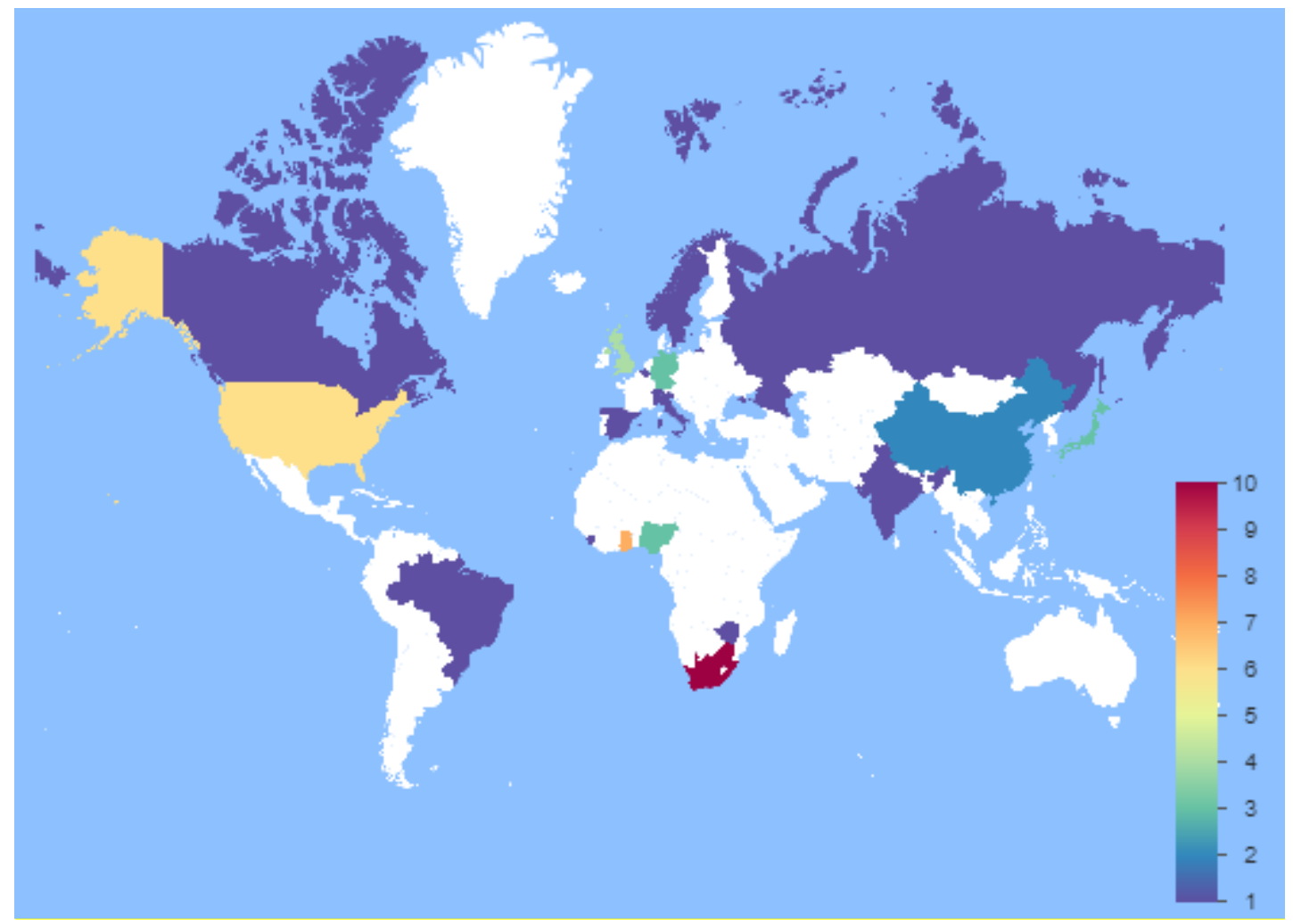

Source: author

The results show that e-waste research by scholars based on the African continent is slightly less (44\%) than research done by scholars based outside the African continent. This indicates that e-waste management issues are becoming prominent in the continent as scholars domiciled in Africa write about topical ecological and human health issues arising from the management of e-waste. South Africa is leading on the number of publications with 10 (20\%) followed by Ghana with 7 (14\%), the United Kingdom with 4 (8\%). Germany, Japan, and Nigeria have three articles $(6 \%)$ each and are fifth. Our study responds to concerns raised by the Global E-waste Monitor (2014) report, which highlighted that a few reports on the state of ewaste in Africa are from African scholars.

\section{Publications and Citations Trends}

The first article on e-waste in Africa was published in 2006, as shown in figure 2. There were no publications between 2007 and 2011 as well as 2018. Publications on e-waste research in Africa have been steadily rising from a single article published in 2006. Two articles were published in 2012 and 2014. 2016 
has three articles, 2015 and 2019 with four, 2017 with five, reaching the peak in 2020 with six articles. This shows that many scholars realise the challenges arising from e-waste management in Africa and raise awareness.

FIGURE 2

TRENDS OF ARTICLES PUBLISHED AND CITATIONS PER YEAR

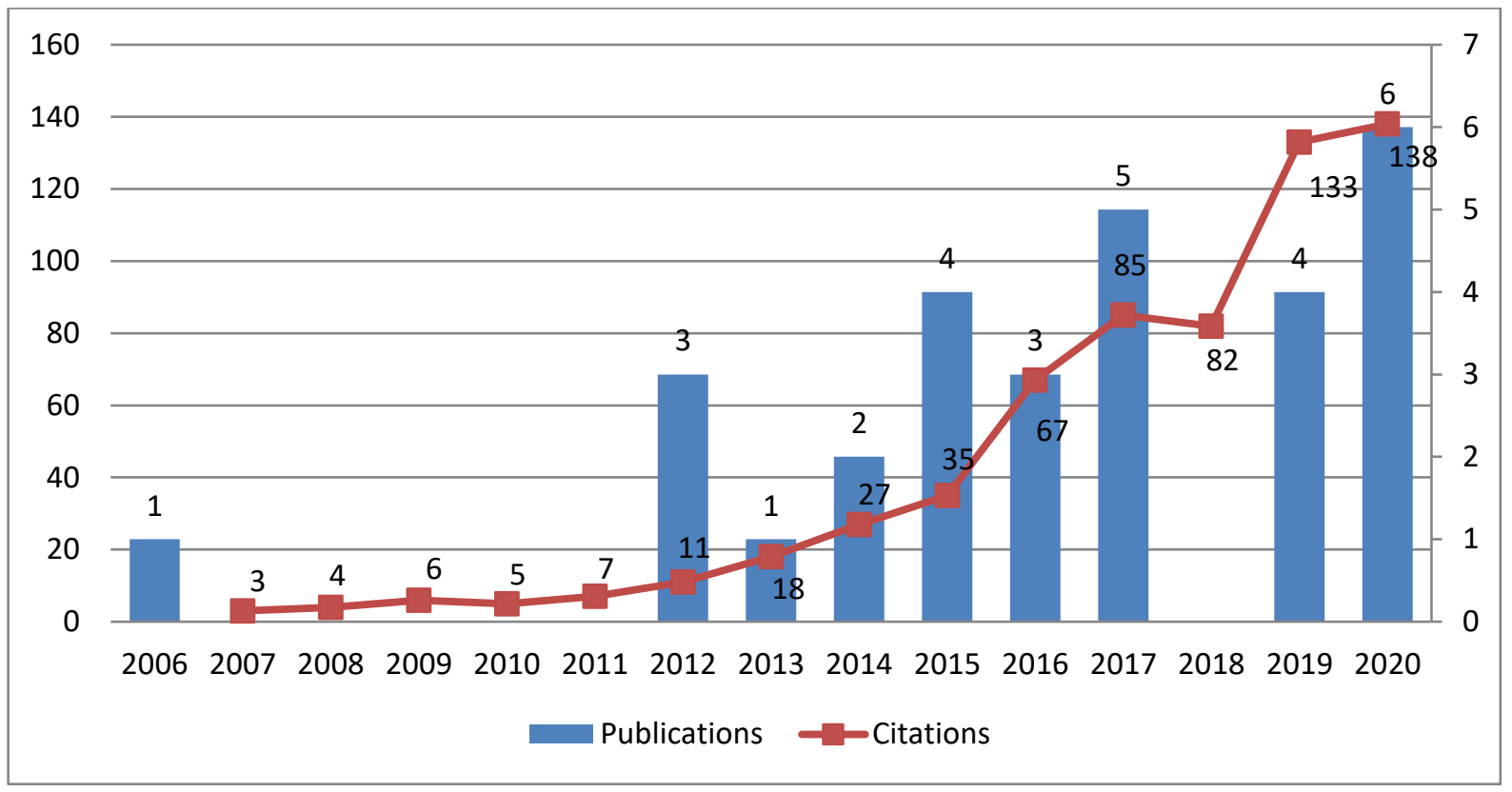

In terms of citations, the first citation of articles on e-waste management was in 2007. Between 2007 and 2011, citations per year were below 10. The years 2012 and 2018 witnessed a significant increase where citations per year ranged between 11 and 85. The years 2019 to 2020 saw over 100 citations, with 2019 having 133 and 2020 having the highest citations (138). Figure 2 shows the trends of articles published and citations per year. As shown, there seems to be a general correlation between the number of articles published and the citations received chronologically.

After applying the advanced query in the Web of Science database, the citation performance for the 29 publications is summarised in the following indicators:

- Average citations per item: 22.28;

- Sum of times cited (without self-citations): 646 (605);

- Citing articles (without self-citations): 514 (500).

\section{Research Topics}

The article analysis shows that 13 research topics and areas are covered in the 29 publications selected. A research article can be classified into more than one research area. The dominate e-waste research area in Africa is environmental sciences ecology $(n=19 ; 43.2 \%)$ followed by engineering $(n=5 ; 11.4 \%)$, public environmental occupational health $(n=4 ; 9.1 \%)$ and science technology $(n=3 ; 6.8 \%)$. E-waste research is multi-disciplinary, but other emerging areas worth noting include criminology, penology, and toxicology, as shown in table 2. The illegal export of e-waste into Africa raises severe environmental and humanitarian crimes, thus seeing the emergency of topics in criminology. 
TABLE 2

RESEARCH AREAS

\begin{tabular}{|l|l|l|}
\hline Research Area & Count & Percentage \\
\hline Environmental Sciences Ecology & 19 & 43.2 \\
\hline Engineering & 5 & 11.4 \\
\hline Public Environmental Occupational Health & 4 & 9.1 \\
\hline Science Technology & 3 & 6.8 \\
\hline Business Economics & 2 & 4.5 \\
\hline Geography & 2 & 4.5 \\
\hline Public Administration & 2 & 4.5 \\
\hline Urban Studies & 2 & 4.5 \\
\hline Chemistry & 1 & 2.3 \\
\hline Criminology Penology & 1 & 2.3 \\
\hline Meteorology Atmospheric Sciences & 1 & 2.3 \\
\hline Social Sciences & 1 & 2.3 \\
\hline Toxicology & 1 & 2.3 \\
\hline Total & 44 & 100 \\
\hline
\end{tabular}

TABLE 3

\section{TOP 10 KEYWORDS}

\begin{tabular}{|l|l|l|}
\hline Rank & Keyword & Occurrence \\
\hline 1 & Site & 11 \\
\hline 2 & South Africa & 10 \\
\hline 3 & Management & 9 \\
\hline 4 & Research & 9 \\
\hline 5 & Paper & 7 \\
\hline 6 & Concentration & 7 \\
\hline 7 & Order & 7 \\
\hline 8 & Policy & 6 \\
\hline 9 & Soil & 6 \\
\hline 10 & World & 6 \\
\hline
\end{tabular}

Table 3 shows the top 10 keywords covered in the 29 research publications analysed. As shown, 'site' is the most frequent keyword appearing in 11 (38\%) research articles. This is expected as research on ewaste focuses on recycling sites or dumping sites where rudimentary e-waste management occurs. South Africa appears in 10 articles (34\%), confirming the earlier finding that the country is leading in terms of publications by authors based in the country. This confirms that research on e-waste management practices of the country is referenced in publications from other countries.

\section{H-Index Analysis}

$\mathrm{H}$-index or $\mathrm{H}$-factor is a widely used technique designed to evaluate an individual and scientific achievement in the academic world (Prathap, 2017). Bornmann and Daniel (2007) state that the H-Index is a reliable and authentic parameter measuring scientific achievement. An advantage of using the H-Index as a performance indicator is that it is readily available and is sensitive to extremely, rarely or frequently cited research papers.

The H-index can be calculated manually or automatically on most subscription-based databases such as Web of Science (Jacsó, 2009). The H-index was retrieved from the Web of Science database for this study. The retrieved research papers have an $\mathrm{H}$-index of 14 . The $\mathrm{H}$-index of 14 means that of the 29 research 
articles, 14 have received at least 14 citations. Given the low number of articles, the H-Index represents a positive observation.

\section{Keyword Analysis}

Keyword analysis has been a prominent research theme in bibliometric studies and involves counting the frequency of keywords to determine hot spots within a research area (Huai \& Chai, 2016). The text data downloaded from the Web of Science database was used to create a term co-occurrence map. In the keyword analysis, structured abstract labels were ignored and copyright statements. There are two options in terms of the counting method, full counting and binary counting. Full counting means that all term occurrences in a document are counted. The other option is to use binary counting, which only counts the presence of a phrase/term in a document and does not consider the frequency. For this study, binary counting was used. In the 29 articles, there are 1119 keywords, of which only seven appear ten times or more, accounting for $0.6 \%$, and 28 appear five times, accounting for $2.5 \%$. Given the small number of occurrences, terms appearing three times or more were included, with $79(7 \%)$ terms meeting this threshold. VOSViewer calculated the 79 words' relevance scores, resulting in 47 keywords (based on $60 \%$ of most relevant keywords).

\section{Network Visualisation Graph}

VOSviewer program was used to generate the network visualisation graphs. Figure 3 shows the network visualisation of the three clusters associated with the research topic from the 79 terms. The circle size depicts the frequency of the occurrence of the term. Different colours represent the clusters. There are three clusters: cluster 1 red, cluster 2 green and cluster 3 blue. Cluster 1 relates to developing e-waste management practices in different countries in Africa, with South Africa being a reference point. The second cluster relates to the effects of e-waste on the environment, such as contamination, burning, and several toxic chemicals in the soil. Finally, the smallest cluster highlights the emerging trends of e-waste research in Africa.

\section{FIGURE 3 \\ KEYWORD CO-OCCURRENCE NETWORK VISUALISATION OF TERMS IN TITLES AND ABSTRACTS}

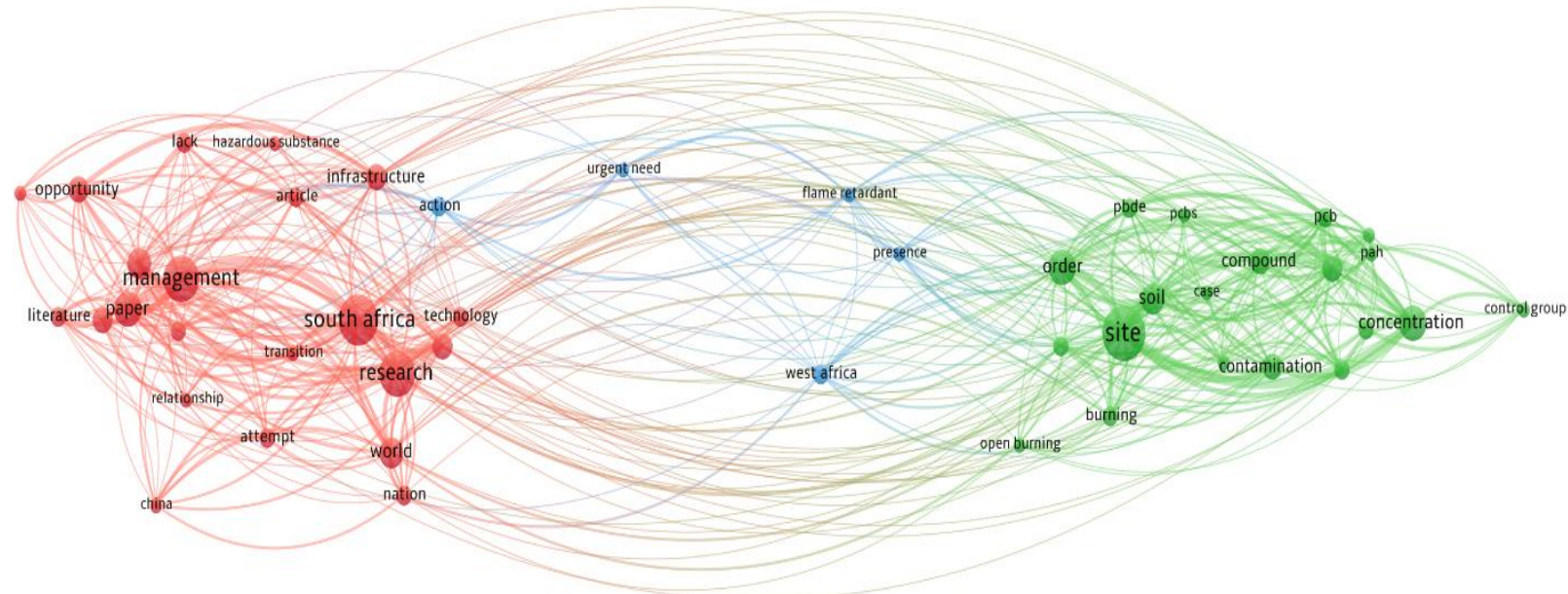

Figure 4 shows the overlay visualisation of various emerging research areas over the years. As shown in figure 4, areas such as relationship and transition appeared in research publications for 2012 and 2013. The majority of research areas appeared in 2017 and 2018. The new dominant topics in research include opportunity, infrastructure, management and hazardous substances. 


\section{FIGURE 4 \\ KEYWORD CO-OCCURRENCE OVERLAY VISUALISATION MAP}

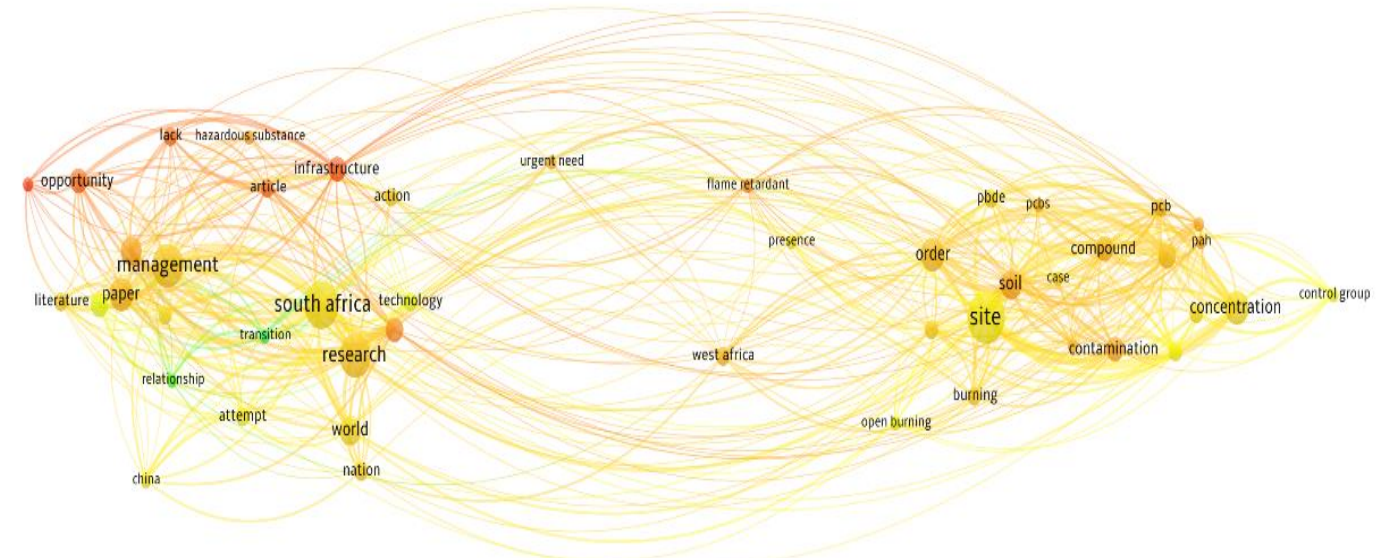

The keyword density visualisation map is shown in Figure 5. Density maps are valuable for understanding the corpus organisation and can help draw attention to the map's most critical areas (Chawla \& Davis, 2013). In VOSviewer, colours indicate the density of terms, ranging from green (lowest density) to red (highest density) (van Eck \& Waltman, 2017). The red area keywords appear more frequently, and the green area keywords appear less often. As shown, the central research theme focuses on 'site', 'South Africa', 'management' and 'research'. The keywords' urgent need', 'West Africa', 'flame retardant' and 'presence' is green indicates that research on these areas is still emerging.

\section{FIGURE 5 \\ KEYWORD DENSITY VISUALISATION MAP}

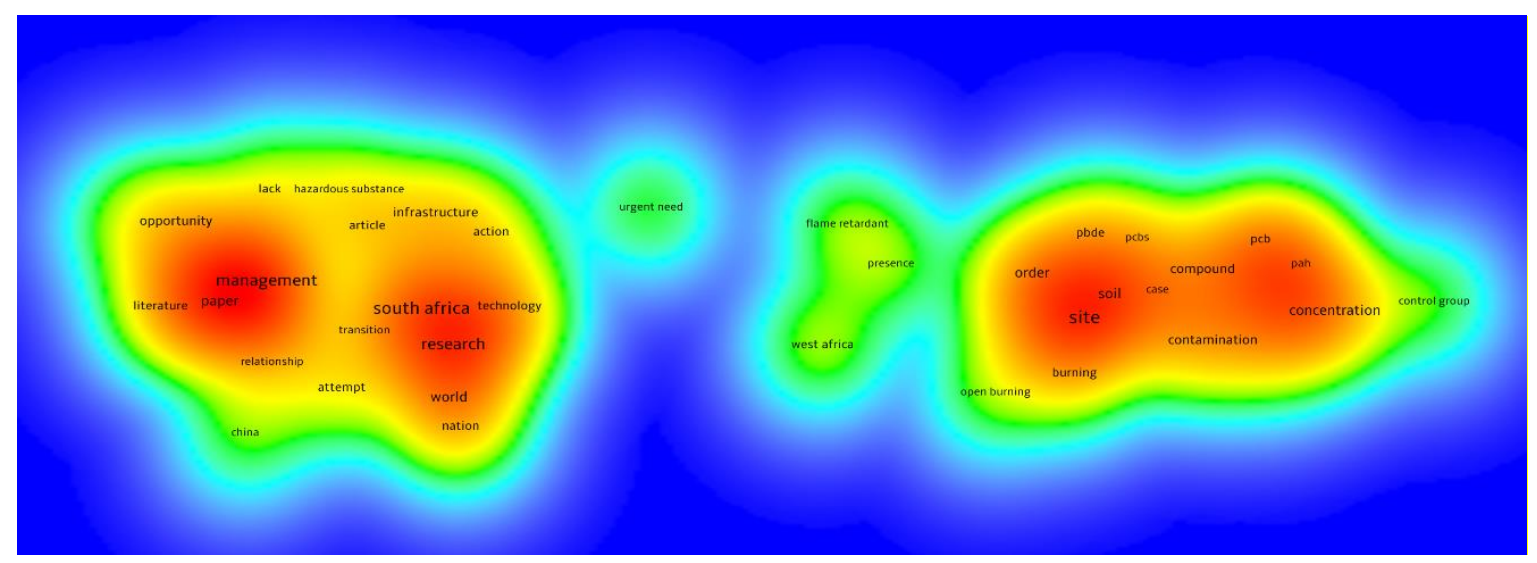

\section{DISCUSSION}

In response to the research questions, the findings are discussed. In terms of the document type, most articles retrieved were original research, a positive finding, given that Africa is a significant recipient of exported e-waste. None of the articles were published under review as book chapters or books. This finding is confirmation that research on e-waste in Africa is still in its infancy. Results show that more scholars researching e-waste management in Africa are based outside the continent. The most industrialised African countries top e-waste research, namely South Africa, Nigeria and Ghana. A steady increase in e-waste research in Africa has been witnessed in the past few years, from a single article published in 2006 to six 
articles in 2020. The articles have an H-Index of 14, which shows positive growth in e-waste research in Africa. The network visualisation's biggest cluster shows e-waste management practices in different countries in Africa, with South Africa dominating the research. The second cluster shows the effects of ewaste on the environment, and the last cluster shows emerging trends in e-waste research, such as criminology penology and toxicology.

E-waste management in Africa has not received due attention in scholarly work and practice, regardless of many policies developed to manage the transboundary movement. Research shows that these regional policies should be complemented with country-specific legislation to deal with the problem of e-waste. Many countries in Africa rely on the informal sector to manage e-waste. There is a need for investment in collecting, transportation, sorting, recovery and disposal processes at a regional and national level. Much research is needed in green computing to ensure that the materials used to manufacture EEE are biodegradable and have reduced toxicity.

\section{Limitation}

Like most bibliometric analyses, the study has a few limitations. The study focused on peer-reviewed publications indexed in Web of Science and could have missed valuable literature published in non-indexed and grey literature. This is particularly true for many African scholars who may not have the experience to contribute to top-end publications. The search also targeted English publications, resulting in the omission of good and relevant publications in other languages.

\section{CONCLUSION}

The bibliometric and visualisation study reveals the state of e-waste management in Africa. The results show that scholars based in South Africa and the USA dominate e-waste research in Africa. Nigeria and Ghana are emerging African countries that significantly contributed to e-waste management studies during the past two decades.

The study provides insight into e-waste management practices and existing regional legislation and shows that e-waste management is similar across various African countries. The research highlights the prominent scholars and leading countries in e-waste management. E-waste generation is fuelled by illegal trade and imports through porous borders, corruption and a lack of strategies to deal with hazardous waste. The results show that informal recycling is Africa's dominant e-waste management practice. The thriving informal sector is driven by a lack of awareness, inadequate government policies, weak collection systems, equipment, and limited sector financing.

\section{REFERENCES}

Adanu, S., Gbedemah, F., \& Attah, K. (2020). Challenges of adopting sustainable technologies in e-waste management at Agbogbloshie, Ghana. Heliyon, 6, e04548. doi: 10.1016/j.heliyon.2020.e04548

Agamuthu, P., Kasapo, P., \& Nordin, N. (2015). E-waste flow among selected institutions of higher learning using material flow analysis model. Resources, Conservation and Recycling, 105, 177185. doi: 10.1016/j.resconrec.2015.09.018

Akon-Yamga, G., Daniels, C., Quaye, W., Ting, B., \& Asante, A. (2021). Transformative innovation policy approach to e-waste management in Ghana: Perspectives of actors on transformative changes. Science and Public Policy, pp. 1-11. doi: 10.1093/scipol/scab005

Bakhiyia, B., Gravela, S., Ceballos, D., Flynnd, M., \& Zayeda, J. (2018). Has the question of e-waste opened a Pandora's box? An overview of unpredictable issues and challenges. Environment International, 110, 173-192. doi: 10.1016/j.envint.2017.10.021

Baldé, C., Forti, V., Gray, V., Kuehr, R., \& Stegmann, P. (2017). The global e-waste monitor 2017. Viena: ITU.

Bornmann, L., \& Daniel, H. (2007). What do we know about the h index? Journal of the American Society for Information Science and Technology, 58(9), 1381-1385. doi: 10.1002/asi.20609 
Chawla, N.V., \& Davis, D.A. (2013). Bringing big data to personalized healthcare: A patient-centered framework. Journal of General Internal Medicine, 28(3), 660-665. doi: 10.1007/s11606-013$2455-8$

European Commission. (2013). Environment: Waste Electrical and Electronic Equipment. Retrieved from http://ec.europa.eu/environment/waste: http://ec.europa.eu/environment/waste/weee/index_en.htm

Forti, V., Baldé, C., Kuehr, R., \& Bel, G. (2020). The Global E-waste Monitor 2020 Quantities, flows, and the circular economy potential. Geneva: United Nations University (UNU).

Garlapati, V. (2016). E-waste in India and developed countries: Management, recycling, business and biotechnological initiatives. Renewable and Sustainable Energy Reviews, 54, 874-881. doi: 10.1016/j.rser.2015.10.106

Herat, S., \& Agamuthu, P. (2012). E-waste: a problem or an opportunity? Review of issues, challenges and solutions in Asian countries. Waste Management Resources, pp. 1-17. doi: $10.1177 / 0734242 \mathrm{X} 12453378$

Hossain, S., \& Rahman, M. (2020). E-Waste Generation and their Impacts on Health and Environment: A Study Over Gazipur District, Bangladesh. International Journal of Innovative Science and Research Technology, 5(7), 1112-1119. doi: 10.38124/IJISRT20JUL756

Ikhlayel, M. (2018). An integrated approach to establish e-waste management systems for developing countries. Journal of Cleaner Production, 170, 119-130. doi: 10.1016/j.jclepro.2017.09.137

Jacsó, P. (2009). Calculating the h-index and other bibliometric and scientometric indicators from Google Scholar with the Publish or Perish software. Online Information Review, 33(6), 1189-1200.

Karin, L. (2012). The global impact of e-waste: Addressing the challenge. Geneva: ILO.

Kazancoglu, Y., Ozbiltekin, M., \& Ozen, Y. (2021). A proposed sustainable and digital collection and classification center model to manage e-waste in emerging economies. Journal of Enterprise Information, 34(1), 267-291. doi:10.1108/JEIM-02-2020-0043

Lepawsky, J., Akese, G., Billah, M., Conolly, C., \& Mcnabb, C. (2015). Urban Worlds - Composing Urban Orders From Rubbish Electronics: Cityness and the Site Multiple. International Journal of Urban and Regional Research, pp. 185-199. doi: 10.1111/1468-2427.12142

Maphosa, V., \& Maphosa, M. (2020). E-waste management in Sub-Saharan Africa: A systematic literature review. Cogent Business \& Management, pp. 1-19. doi:10.1080/23311975.2020.1814503

Marriott, S. (2011, September 7). E-waste: A growing environmental problem for Africa S. SANGONeT: NGO News \& Views. Retrieved February 4, 2021, from http://www.ngopulse.org/article/e-wastegrowing-environmental-problem-africa

Miner, K., Rampedi, I., Ifegbesan, A., \& Machete, F. (2020). Survey on Household Awareness and Willingness to Participate in E-Waste Management in Jos, Plateau State Nigeria. Sustainability, 12(1067), 1-16. doi: 10.3390/su12031047

Mutsau, S., Billiat, E., \& Musingafi, M. (2015). Electronic Waste Management in Zimbabwe: A Slow Onset Public Health Disaster. Civil and Environmental Research, 7(10), 84-87.

Nnorom, I., \& Osibanjo, O. (2008). Overview of electronic waste (e-waste) management practices and legislations, and their poor applications in the developing countries. Resources, Conservation and Recycling, 52, 843-858.

Odeyingbo, O., Nnorom, I., \& Deubzer, O. (2017). Person in the Port Project-Assessing Import of Used Electrical and Electronic Equipment into Nigeria. Retrieved from http://collections.unu.edu/eserv/UNU: http://collections.unu.edu/eserv/UNU:6349/PiP_Report.pdf

Olowu, D. (2012). Menace of E-Wastes in Developing Countries: An Agenda for Legal and Policy Responses'. Law, Environment and Development Journal, pp. 59-68. Retrieved from http://www.lead-journal.org/content/12059.pdf

Oteng-Ababioa, M., \& Amankwaa, E. (2014). The e-waste conundrum: Balancing evidence from the North and on-the-ground developing countries' realities for improved management. African Review of Economics and Finance, 6(1), 181-204. 
Perkins, D., Drisse, M., Nxele, T., \& Sly, P. (2014). E-Waste: A Global Hazard. Annals of Global Health, 80(4), 286-295. doi: 10.1016/j.aogh.2014.10.001

Prathap, G. (2017). Letter to the editor: Comments on the paper of Lucio Bertoli-Barsotti and Tommaso Lando: a theoretical model of the relationship between the h-index and other simple citation indicators. Scientometrics, 112, 1133-1136. doi: 10.1007/s11192-017-2404-0

Rajaram, V., \& Pekeur, S. (2014). Assessing e-waste management within the Mangaung metropolitan municipality, South Africa. Arabian Journal of Business and Management Review (OMAN Chapter), 3(11), 1-40. http://dx.doi.org/10.12816/0016518

Rampedi, I., Miner, K., Ifegbesan, A., \& Machete, F. (2020). Survey on Household Awareness and Willingness to Participate in E-Waste Management in Jos, Plateau State, Nigeria. Sustainability, 12(1047), 1-16. doi: 10.3390/su12031047

Schluep, M. (2010). E-Waste Management in Developing Countries - with a focus on Africa. ITU Symposium on ICTs and the Environment \& Climate Change (pp. 1-28). Cairo: ITU.

Schmidt, C. (2006). Unfair Trade E-Waste in Africa. Environmental Health Perspectives, 114, 232-235. doi: 10.1289/ehp.114-a232

Sovacool, B. (2019). Toxic Transitions in the Lifecycle Externalities of a Digital Society: The Complex Afterlives of Electronic Waste in Ghana. Resources Policy, 64, 101459. doi:10.1016/j.resourpol.2019.101459

Terad, C. (2012). Recycling Electronic Wastes in Nigeria: Putting Environmental and Human Rights at Risk. Northwestern Journal of International Human Rights, 10(3), 154-172.

The Global E-waste Monitor. (2014). Retrieved February 12, 2021, from http://i.unu.edu/media/ias.unu.edu-en/news/7916/Global-E-waste-Monitor-2014-small.pdf

UN-DESA. (2014, July 10). 2014 revision of the World Urbanization Prospects. Retrieved from https://www.un.org/en/development/desa/publications: https://www.un.org/en/development/desa/publications/2014-revision-world-urbanizationprospects.html

UNEP. (n.d.). The Bamako convention. Retrieved from https://www.unep.org/exploretopics/environmental-rights-and-governance/what-we-do/meeting-international-environmental

van Eck, N.J., \& Waltman, L. (2017). VOSviewer manual: Manual for VOSviewer version 1.6.11. Leiden: Leiden University.

Wang, W., Tian, Y., Zhu, Q., \& Zhong, Y. (2017). Barriers for household e-waste collection in China: Perspectives from formal collecting enterprises in Liaoning Province. J. Clean. Prod, 153, 299 308. doi: 10.1016/j.jclepro.2017.03.202

Widmer, R., Oswald-Krapf, H., Sinha-Khetriwal, D., Schnellmann, C., \& Boni, H. (2005). Global perspectives on e-waste. Environmental Impact Assessment Review, 25, 436-458. doi:10.1016/j.eiar.2005.04.001

Yu, E., Akormedi, M., Asampong, E., Meyer, C., \& Fobil, J. (2017). Informal processing of electronic waste at Agbogbloshie, Ghana: Workers' knowledge about associated health hazards and alternative livelihoods. Global Health Promotion, 24(4), 90-98. doi:10.1177/1757975916631523

Zeng, X., \& Li, J. (2016). Measuring the recyclability of e-waste: An innovative method and its implications. J Clean Prod, 131, 156-162. doi: 10.1016/j.jclepro.2016.05.055 